\title{
FAKTOR-FAKTOR YANG MEMPENGARUHI PENERIMAAN PEMBUDIDAYA IKAN DI RANUPAKIS KECAMATAN KLAKAH KABUPATEN LUMAJANG
}

\author{
Oleh :
}

FRANSISKA*), IDA ADHA AP dan RIZAL PERLAMBANG CNAWP*)

\begin{abstract}
ABSTRAK
Tujuan penelitian ini adalah untuk mengetahui pengaruh faktor pakan, unit keramba, dan tenaga kerja terhadap penerimaan pembudidaya ikan, serta mengetahui faktor manakah yang paling dominan terhadap penerimaan pembudidaya ikan. Metode penelitian yang digunakan adalah survei dengan teknik pengambilan data melalui wawancara langsung. Metode analisis data yang digunakan dalam penelitian ini yaitu analisis regresi linear berganda untuk mengetahui faktor-faktor yang mempengaruhi penerimaan pembudidaya ikan. Yang dirumuskan dalam fungsi sebagai berikut: $\boldsymbol{Y}=$ $\boldsymbol{a}+\boldsymbol{b}_{1} \boldsymbol{X}_{\boldsymbol{1}}+\boldsymbol{b}_{2} \boldsymbol{X}_{2}+\boldsymbol{b}_{3} \boldsymbol{X}_{3}$. Hasil uji-F menunjukkan bahwa variabel pakan, unit keramba, dan tenaga kerja berpengaruh signifikan terhadap penerimaan pembudidaya ikan. Sedangkan hasil uji-t menunjukkan bahwa hanya satu variabel bebas yang berpengaruh signifikan terhadap penerimaan pembudidaya ikan, yaitu variabel unit keramba.
\end{abstract}

Kata kunci: penerimaan, pembudidaya ikan, faktor yang mempengaruhi 


\section{PENDAHULUAN}

\subsection{Latar Belakang}

Indonesia merupakan negara kepulauan yang di dalamnya terdapat berbagai macam potensi. Sebagian besar wilayah Indonesia merupakan daerah lautan dengan luas mencapai 5,8 juta $\mathrm{km}$ persegi (75 persen dari luas total wilayah) dengan garis pantai $81.000 \mathrm{~km}$ atau sekitar 14 persen dari garis pantai dunia. Dengan demikian wilayah geografis negara Indonesia mempunyai potensi yang besar dalam pengembangan sektor perikanan.

Pembangunan kelautan dan perikanan merupakan salah satu sektor yang mendapat perhatian dan prioritas yang cukup tinggi bagi pemerintah Indonesia, terlebih dengan dibentuknya Departemen Kelautan dan Perikanan. Hal ini membuktikan bahwa pada masa yang akan datang intensitas dan penetrasi pembangunan perikanan akan semakin baik dari segi kualitas maupun segi kuantitasnya.

Pembangunan perikanan Indonesia merupakan suatu usaha pengembangan perikanan di semua wilayah yang berpotensi. Potensi sumberdaya perikanan terdiri dari sumberdaya perikanan air tawar dan perikanan air laut. Potensi perikanan air tawar masih terbuka lebar baik pada sawah, kolam, maupun keramba.

Salah satu daerah yang memiliki potensi sumber daya perikanan yang cukup besar adalah Kabupaten Lumajang. Potensi ini dimanfaatkan secara optimal untuk usaha perikanan tangkap, budidaya, pengolahan, maupun aqua wisata. Kabupaten Lumajang yang terletak pada $112^{\circ} 54^{\prime}$ $113^{\circ} 23^{\prime}$ Bujur Timur dan $7^{\circ} 54^{\prime}-8^{\circ} 23^{\prime}$ Lintang Selatan dengan luas $1.790,98 \mathrm{~km}^{2}$, yang wilayahnya memiliki sumber daya perikanan yang cukup besar. Kabupaten Lumajang memiliki banyak potensi sumber daya perairan air tawar yang berhabitat di danau, rawa, dan sungai.

Salah satu tempat budidaya ikan air tawar di Kabupaten Lumajang yang cukup terkenal yaitu Ranu Pakis. Ranu pakis terletak di Desa Ranu Pakis dengan jarak $\pm 20,5 \mathrm{~km}$ di sebelah Utara kota Lumajang. Ketinggian Ranu ini mencapai 600 meter dpl dengan luas danau 112 ha dan kedalaman \pm 26 meter. Sistem budidaya yang digunakan di Ranu Pakis yaitu sistem keramba jaring apung dengan komoditas ikan yang dibudidayakan yaitu ikan nila dan mujair.

Komoditas yang dibudidayakan banyak digemari masyarakat baik di sekitar Ranu Pakis maupun diluar daerah. Hal ini disebabkan harga ikannya terjangkau serta rasanya gurih, ini merupakan salah satu sumber pendapatan bagi pembudidaya. Namun ikan yang terjual laris tidak serta merta menguntungkan bagi pembudidaya. Penerimaan yang mereka peroleh dari hasil penjualan ikan masih tergantung dari beberapa faktor. Oleh karena itu, peneliti akan menganalisis faktor-faktor apa saja yang mempengaruhi penerimaan pembudidaya ikan air tawar di Ranu Pakis. Beberapa faktor yang akan dikaji yaitu, pakan, unit keramba, dan tenaga kerja.

\section{METODE PENELITIAN}

\subsection{Desain Penelitian}

Penelitian yang ini merupakan desain penelitian dalam bentuk survei. Menurut Kraemer (1991), survei adalah alat atau cara untuk mengumpulkan informasi tentang karakteristik, tindakan atau aksi, dan opini dari sekelompok besar individu, grup, organisasi atau entiti lain yang mengacu sebagai suatu populasi.

Analisis data yang digunakan dalam penelitian ini yaitu analisis regresi linear berganda yang merupakan persamaan regresi dengan tiga variabel $\mathrm{X}$. Dalam penelitian ini menjelaskan pengaruh pakan, unit keramba, dan tenaga kerja terhadap penerimaan pembudidaya ikan di Desa Ranu Pakis, Kecamatan Klakah, Kabupaten Lumajang.

\subsection{Populasi dan Sampel}

Menurut Sugiyono (2010), populasi adalah wilayah generalisasi yang mempunyai kuantitas dan karakteristik tertentu yang ditetapkan peneliti untuk kemudian dipelajari dan kemudian ditarik kesimpulannya. Populasi penelitian ini adalah seluruh pembudidaya ikan yang melakukan kegiatan budidaya di Ranu Pakis, Kecamatan Klakah Kabupaten Lumajang yang berjumlah 35 orang.

Sampel adalah sebagian atau wakil populasi yang akan diteliti (Arikunto 2010). Metode penelitian dilakukan dengan cara sensus. Menurut Masri Singarimbun dan Sofyan Effendi (1989:3) sensus yaitu penelitian yang datanya dikumpulkan dari seluruh populasi. Karena menggunakan sensus maka teknik pengambilan sampel tidak diperlukan.

\subsection{Instrumen Penelitian}

Sesuai dengan rumusan masalah dan tujuan penelitian, dalam penelitian ini instrumen penelitian berupa dokumentasi yaitu kamera dan beberapa daftar pertanyaan wawancara. Wawancara merupakan metode pengumpulan data dengan jalan tanya jawab sepihak yang dilakukan secara sistematis dan berlandaskan 
kepada tujuan penelitian (Lerbin, 1992 dalam Hadi, 2007). Tanya jawab sepihak berarti bahwa pengumpul data yang aktif bertanya sementara pihak yang ditanya aktif memberikan jawaban atau tanggapan.

Instrumen penelitian ini menggunakan kuisioner terbuka yaitu wawancara langsung kepada pembudidaya ikan di Ranu Pakis, Kecamatan Klakah, Kabupaten Lumajang yang berjumlah 35 orang.

\subsection{Waktu dan Lokasi Penelitian}

Penelitian ini dilaksanakan selama 5 (lima) bulan yaitu pada tanggal 12 September Desember 2014 dan dilaksanakan di Ranu Pakis, Desa Ranupakis, Kecamatan Klakah Kabupaten Lumajang. Penentuan lokasi dilakukan secara sengaja atas dasar pertimbangan bahwa Desa Ranu Pakis merupakan salah satu tempat di Kabupaten Lumajang yang sangat berpotensi dalam bidang perikanan air tawar. Dimana Desa Ranu Pakis ini memiliki sebuah danau/telaga yang cukup luas yaitu \pm 112 hektar yang potensial dalam usaha perikanan air tawar.

\subsection{Definisi Operasional}

Berdasarkan pokok permasalahan yang diajukan maka variabel-variabel yang dianalisis dapat didefinisikan sebagai berikut:

1. Variabel terikat atau dependent variable (Y) adalah penerimaan pembudidaya ikan di Ranu Pakis yaitu selisih antara total produksi dengan harga jual yang diukur dalam rupiah.

2. Variabel bebas atau independent variable $(\mathrm{X})$ adalah faktor sosial ekonomi yang mempengaruhi tingkat penerimaan pembudidaya ikan yang meliputi:

a. Pakan $\left(\mathrm{X}_{1}\right)$ yaitu nutrisi yang dibutuhkan oleh ikan sebagai penunjang pertumbuhan dan kelangsungan hidup ikan. Pakan dalam penelitian ini diukur dalam kilogram yang akan dihitung harganya dalam rupiah.

b. Unit Keramba (X2) yaitu jumlah keramba yang dimiliki setiap pembudidaya untuk usaha budidaya ikan. Penelitian ini memperhitungkan unit keramba sesuai dengan ukuran masing-masing keramba yang dihitung harganya dalam rupiah.

c. Tenaga kerja (X3) yaitu orang-orang yang dipekerjakan dalam usaha pemeliharaan ikan dalam keramba. Upah tenaga kerja diukur dalam rupiah.

\subsection{Prosedur Pengumpulan Data}

Pengumpulan data dalam penelitian ini diambil dari dua sumber, yaitu sumber data primer dan data sekunder. Data primer diperoleh dari hasil pengamatan langsung di lokasi penelitian. Data sekunder diperoleh dari instansi-instansi terkait yang mendukung data primer.
Berdasarkan tujuan penelitian yang telah ditetapkan, maka perlu untuk menganalisis data yang telah dikumpulkan. Metode analisis data yang digunakan dalam penelitian ini yaitu analisis regresi linear berganda untuk mengetahui faktorfaktor yang mempengaruhi penerimaan pembudidaya ikan. Yang dirumuskan dalam fungsi sebagai berikut:

$Y=a+b_{1} X_{1}+b_{2} X_{2}+b_{3} X_{3}$

Keterangan:

$\mathrm{Y} \quad=$ Penerimaan $(\mathrm{Rp})$

a $\quad=$ Konstanta

$\mathrm{X}_{1} \quad=$ Pakan $(\mathrm{Rp})$

$\mathrm{X}_{2} \quad=$ Unit keramba (Rp)

$\mathrm{X}_{3} \quad=$ Tenaga kerja $(\mathrm{Rp})$

Hipotesis yang telah diajukan diuji dengan menggunakan uji statistik. Diantaranya uji-F, uji-t, dan koefisien determinasi. Uji statistik tersebut dijabarkan sebagai berikut:

1. Uji-F

Uji-F digunakan untuk menguji pengaruh seluruh variabel independen terhadap variabel dependen kemudian menggunakan tabel Anova yang dianalisis menggunakan program SPSS (Statistic Program for Social Science). Taraf signifikansi dalam uji ini yaitu $5 \%$ dan kriteria pengambilan keputusan dalam uji-F dijabarkan sebagai berikut:

a. Jika $\mathrm{F}_{\text {-hitung }}<\mathrm{F}$ 0,05, maka variabel independen secara bersama-sama tidak berpengaruh terhadap variabel dependen (penerimaan).

b. Jika $\mathrm{F}_{\text {-hitung }}>\mathrm{F}$ 0,05, maka variabel independen secara bersama-sama berpengaruh terhadap variabel dependen (penerimaan).

2. Uji-t

Uji-t digunakan untuk mengetahui variabelvariabel independen secara parsial terhadap variabel dependen. Pengujian dilakukan dengan menggunakan program SPSS (Statistic Program for Social Science). Kriteria pengambilan keputusan dalam uji-t sebagai berikut:

a. Jika t-hitung $<\mathrm{t} 0,05$, maka variabel independen berpengaruh tidak signifikan terhadap variabel dependen, sedangkan variabel independen lain dianggap konstan.

b. Jika t-hitung $>\mathrm{t}$ 0,05, maka variabel independen berpengaruh signifikan terhadap variabel dependen, sedangkan independen lain dianggap konstan.

3. Koefisien Determinasi

Hubungan antar variabel dapat dilihat dengan menghitung koefisien determinasi yang perhitungannya menggunakan program SPSS. Koefisien determinasi digunakan untuk menguji seberapa jauh hubungan variabel Y (variabel 
terikat) terhadap variasi -variabel X (variabel bebas).

\section{HASIL DAN PEMBAHASAN}

\section{Hasil}

Hartono (2008:110), rumus yang digunakan pada regresi ganda sama seperti pada regresi tunggal (sederhana), hanya saja pada regresi ganda ditambahkan variabel-variabel lain yang juga diikutsertakan dalam penelitian. Rumus yang dipakai disesuaikan dengan jumlah variabel yang diteliti. Misalnya untuk 3 (tiga) jumlah prediktor, dengan persamaan sebagai berikut:

$\mathrm{Y}=\mathrm{a}+\mathrm{b} 1 \mathrm{X} 1+\mathrm{b} 2 \mathrm{X} 2+\mathrm{b} 3 \mathrm{X} 3$

Keterangan:

$$
\begin{array}{ll}
\mathrm{Y} & =\text { Penerimaan }(\mathrm{Rp}) \\
\mathrm{a} & =\text { Konstanta } \\
\mathrm{X}_{1} & =\text { Pakan }(\mathrm{Rp}) \\
\mathrm{X}_{2} & =\text { Unit keramba }(\mathrm{Rp}) \\
\mathrm{X}_{3} & =\text { Tenaga kerja (Rp) }
\end{array}
$$

\subsection{Hasil Perhitungan Regresi Linear Berganda} a. Persamaan

Hasil analisis dengan menggunakan uji linier berganda menghasilkan persamaan sebagai berikut:

$Y=-259871.172+0,185 X_{1}+1.096 X_{2}+0,583 X_{3}$

Persamaan regresi linear berganda dapat diinterpretasikan bahwa apabila tidak ada biaya yang dikeluarkan untuk pakan, keramba dan upah tenaga kerja dapat diasumsikan bahwa penerimaan mengalami penurunan sebanyak -259871,172. Apabila harga pakan dinaikan Rp.10.000, biaya pembuatan keramba dinaikkan Rp.1.000.000 dan biaya tenaga kerja dinaikkan sebanyak Rp.100.000 maka $\mathrm{Y}=-259871,172+1.850+1.096 .000+$ 58.300 maka diperoleh peneriman sebesar Rp. 896.278,828.

\subsection{Hasil Uji-F dan Uji-t}

Pengujian terhadap pengaruh semua variabel independen di dalam model dapat dilakukan dengan uji serempak (uji-F). Pengujian ini bertujuan untuk mengetahui pengaruh semua variabel independen yang terdapat dalam model secara bersama-sama terhadap variabel dependen (Algifari, 2000).

Berdasarkan hasil hasil yang diperoleh selama penelitian bahwa faktor pakan, unit keramba dan tenaga kerja berpengaruh terhadap penerimaan pembudidaya ikan terdapat F-hitung lebih besar dari F 0,05. Oleh karena itu secara bersama-sama variabel pakan, unit keramba dan tenaga kerja mempengaruhi penerimaan pembudidaya ikan di Ranu Pakis, Kecamatan Klakah Kabupaten Lumajang.

Uji statistik-t dilakukan untuk menunjukkan seberapa jauh pengaruh satu variabel penjelas atau independen secara individual dalam menerangkan variasi variabel dependen (Ghozali, 2005).

Berdasarkan hasil yang diperoleh selama penelitian bahwa faktor pakan, unit keramba dan tenaga kerja berpengaruh terhadap penerimaan pembudidaya ikan, secara parsial variabel pakan memiliki nilai t-hitung lebih besar dari t 0,05 . Variabel unit keramba memiliki nilai t-hitung lebih besar dari t 0,05. Variabel tenaga kerja memiliki nilai t-hitung lebih besar dari t 0,05 . Oleh karena itu secara parsial variabel pakan, unit keramba dan tenaga kerja masing-masing mempengaruhi penerimaan pembudidaya ikan di Ranu Pakis, Kecamatan Klakah Kabupaten Lumajang. Variabel bebas yang berpengaruh paling dominan terhadap penerimaan pembudidaya ikan di Ranu Pakis, Kecamatan Klakah, Kabupaten Lumajang yaitu variabel unit keramba.

\section{Pembahasan}

2.1 Faktor - Faktor Yang Mempengaruhi Penerimaan Pembudidaya Ikan di Ranu Pakis, Kecamatan Klakah, Kabupaten Lumajang

Keseluruhan faktor pakan, unit keramba dan tenaga kerja mempengaruhi penerimaan pembudidaya ikan di Ranu Pakis, Kecamatan Klakah, Kabupaten Lumajang. Hasil uji-F menunjukkan secara bersama-sama faktor pakan, unit keramba dan tenaga kerja mempengaruhi penerimaan pembudidaya ikan di Ranu Pakis, Kecamatan Klakah, Kabupaten Lumajang. Hasil uji-t menunjukkan faktor pakan, unit keramba, dan tenaga kerja masing-masing mempengaruhi penerimaan pembudidaya ikan di Ranu Pakis, Kecamatan Klakah, Kabupaten Lumajang.

Keseluruhan variabel mempunyai pengaruh baik secara serempak maupun parsial. Namun variabel yang mempunyai pengaruh dominan yaitu unit keramba. Hal ini sesuai dengan hipotesis yang menyatakan bahwa salah satu faktor manakah yang berpengaruh paling dominan.

Secara umum uji statistik menunjukkan bahwa unit keramba berpengaruh sangat nyata terhadap penerimaan pembudidaya ikan di Ranu Pakis, Kecamatan Klakah, Kabupaten Lumajang. Hal ini disebabkan harga pembelian keramba tidak mengalami fluktuasi. Dimana biaya pembuatan keramba dari tahun ke tahun tetap dan stabil. Selain itu keramba yang digunakan merupakan keramba yang cukup kokoh walaupun teknologi budidaya yang digunakan masih tergolong semi intensif. Dimana bahan-bahan yang digunakan sebagai kerangka terbuat dari bambu. Akan tetapi para pembudidaya ikan bisa menyikapi hal tersebut dengan cara melapisi kerangka-kerangka tersebut dengan karpet atau aluminium. Sehingga bahan yang tadinya tergolong sederhana dan umur 
teknisnya tidak bertahan lama menjadi kokoh dan secara teknis pemakaiannya bisa mencapai lima sampai sepuluh tahun.

Tidak hanya tersedia alat-alat pelengkap juga terdapat rumah jaga yang berfungsi sebagai tempat mengontrol ikan-ikan yang dibudidayakan. Rumaha jaga sangat membantu para tenaga kerja dengan sigap melakukan pengontrolan jika sewaktu-waktu ikan yang dibudidayakan terserang hama dan lain sebagainya. Selain itu luas keramba juga sangat menentukan besar kecilnya faktor produksi. Semakin banyak dan semakin luas keramba yang digunakan maka semakin besar jumlah produksi. Jumlah produksi yang besar akan meningkatkan penerimaan.

Pakan berpengaruh terhadap penerimaaan pembudidaya ikan di Ranu Pakis, Kecamatan, Klakah, Kabupaten Lumajang. Namun pengaruh pakan tidak dominan. Pakan merupakan faktor utama untuk pertumbuhan ikan. Jumlah pakan yang diberikan mempengaruhi pertumbuhan ikan. Selain jumlah, kualitas pakan yang baik juga sangat mempengaruhi pertumbuhan ikan. Jika asupan pakan diberikan sesuai dengan proporsi maka sudah tentu pertumbuhan ikan-ikan yang dibudidayakan tersebut baik.

Pakan merupakan salah satu aspek yang memerlukan perhatian cukup besar

sehingga harus direncanakan dengan matang yaitu menekan anggaran

pengeluaran serendah mungkin, tetapi hasilnya tetap optimal. Hal ini dapat dilakukan dengan cara pemilihan jenis pakan yang tepat namun tetap mempertimbangkan kualitas nutrisi, selera ikan, dan harga yang murah.

Tujuan untuk mendapatkan hasil yang baik dengan pengeluaran yang relatif rendah adalah dengan memberikan pakan dari jenis ikan-ikan yang tak laku di pasaran (non-ekonomis). Namun hal tersebut berbanding terbalik dengan apa yang terjadi di Ranu Pakis ini. Pemberian pakan dilakukan ala kadarnya dengan tidak memperhatikan kandungan nutrisi yang terdapat dalam pakan tersebut. Kebanyakan dari pembudidaya ikan hanya berpatokan dengan harga yang murah tetapi tidak mempertimbangan kandungan nutrisi yang dibutuhkan oleh ikan.

Tidak hanya kandungan nutrisi saja yang kurang diperhatikan, pemberian pakan yang dilakukan kurang efektif dimana pemberian pakan itu dilakukan sewaktu-waktu saja dan tidak memperhatikan apakah ikan yang diberi pakan benar-benar kenyang atau tidak. Hal ini disebabkan kurangnya pengetahuan tentang manajemen pemberian pakan.

Tidak hanya faktor pakan dan unit keramba, tenaga kerja juga mempengaruhi penerimaan pembudidaya ikan di Ranu Pakis, Kecamatan Klakah, Kabupaten Lumajang. Namun pengaruh tenaga kerja tidak dominan, hal ini disebabkan tenaga kerja bekerja tidak secara intens dimana dalam perawatan dan dalam pemberian pakan tidak rutin dilakukan dan seringkali yang melakukan pekerjaan yang harusnya dilakukan oleh tenaga kerja diambil alih oleh pembudidaya itu sendiri. Selain itu tenaga kerja yang dipekerjakan tidak produktif. Dimana tenaga kerja yang dipekerjakan tidak memiliki keterampilan dalam bidang budidaya ikan. Pemilihan tenaga kerja dilakukan atas dasar kemauan semata dari kedua pihak tanpa memperhatikan keterampilan apa saja yang dimiliki oleh seorang calon tenaga kerja sebelum memilih tenaga kerja tersebut. Padahal produktivitas tenaga kerja sangat menentukan dalam produksi.

Tenaga kerja merupakan faktor penggerak faktor input yang lain, tanpa adanya tenaga kerja maka faktor produksi lain tidak akan berjalan dengan baik. Dengan meningkatnya produktivitas dan jumlah tenaga kerja akan mendorong peningkatan produksi sehingga penerimaan pun akan ikut meningkat. Kurangnya produktivitas tenaga kerja disebabkan kurangnya pengetahuan dimana para tenaga kerja tidak pernah mengikuti pendidikan formal dan non formal berupa pelatihan-pelatihan khusus mengenai usaha budidaya ikan.

Berdasarkan pedoman koefisien korelasi diatas, dalam penelitian ini hubungan antara pakan, unit keramba dan tenaga kerja dengan penerimaan sangat kuat. Hal ini berarti ada korelasi positif dan signifikan antara pakan, unit keramba, dan tenaga kerja dengan penerimaan. Oleh karena itu, untuk meningkatkan penerimaan sangat efektif dengan cara meningkatkan biaya pakan, unit keramba dan tenaga kerja. Semakin tinggi biaya pakan, unit keramba, dan tenaga kerja maka penerimaan semakin meningkat.

\section{KESIMPULAN DAN SARAN 1. KESIMPULAN}

Berdasarkan hasil penelitian pada faktorfaktor yang mempengaruhi penerimaan pembudidaya ikan, maka dapat diambil beberapa kesimpulan sebagai berikut:

1. Keseluruhan faktor pakan, unit keramba, dan tenaga kerja secara serempak berpengaruh terhadap penerimaan pembudidaya ikan di Ranu Pakis, Kecamatan Klakah, Kabupaten Lumajang.

2. Faktor pakan, unit keramba, dan tenaga kerja secara parsial berpengaruh terhadap penerimaan pembudidaya ikan di Ranu Pakis, Kecamatan Klakah, Kabupaten Lumajang. Namun faktor yang paling berpengaruh yaitu unit keramba 


\section{SARAN}

Beberapa saran yang dapat disampaikan sehubungan dengan penelitian tentang penerimaan pembudidaya ikan adalah:

1. Usaha budidaya ikan dengan menggunakan keramba jaring apung (KJA) sangat menguntungkan sehingga pembudidaya ikan diharapkan untuk terus mengembangkan kegiatan budidayanya. Sebaiknya tingkatkan kualitas keramba sehingga hasil produksinya baik dan terus meningkat.

2. Untuk memperoleh penerimaan yang besar, pembudidaya ikan disarankan untuk meningkatkan faktor produksi, misalnya luas keramba. Karena dengan penggunaan faktor produksi yang tinggi akan meningkatkan jumlah produksi, dan jumlah produksi yang meningkat mampu meningkatkan penerimaan.

3. Pembudidaya ikan disarankan untuk menambah pengetahuan tentang budidaya melalui pelatihan-pelatihan khusus.

\section{DAFTAR PUSTAKA}

Adhar. 2012. Analisis Faktor-Faktor Yang Mempengaruhi Tingkat Pendapatan Usaha Nelayan Di Kabupaten Bone. Skripsi S1. Universitas Hasanuddin. Makassar.

Adnan. 2006. Hubungan Program Motorisasi Terhadap Peningkatan Produksi dan Pendapatan nelayan. Skripsi S1. USU. Medan

Algifari. 2000. Analisis Regresi : Teori, Kasus, dan Solusi. Edisi 2. BPFE. Yogyakarta

Djarwanto. 2001. Statistik Sosial Ekonomi: Yogyakarta: BPFE.

Gaspersz, Vincent. 1996. EKONOMI MANAJERIAL. Penerapan KonsepKonsep Ekonom Dalam MANAJEMEN BISNIS TOTAL. Gramedia Pustaka Utama: Jakarta
Hartono. 2008. Analisis Data Statistika Dan Penelitian. Yogyakarta: LSFK2P

Kurniati. 2013. Manajemen Pakan. Elek Media. Bandung.

M. Isbah Al Atsili 2010. Faktor-Faktor Yang Mempengaruhi Pendapatan Petani Tambak Bandeng Di Kabupaten Gresik Studi Kasus Di Desa Wadak Kidul Kecamatan Duduk Sampeyan. Skripsi S1. USU.Medan

Mardalis. 2004. Metode Penelitian Suatu Pendekatan Proposal. Bumi Aksara. Jakarta.

Moh. Haris Syafii. 2012. Analisis faktor-faktor YangMempengaruhi Pendapatan Budidaya Ikan Bandeng Di Kabupaten Pati Jawa Tengah. Skripsi S1. Universitas Islam Indonesia. Yogyakarta

Nazir, M. 1999. Metode Penelitian. Jakarta: Ghalilea Indonesia.

Sasmita. 2006. Analisis Faktor-Faktor Yang Mempengaruhi Usaha Nelayan Di Kabupaten Asahan. Tesis S2. PPS USU. Medan.

Singarimbun, M dan Effendi, S. 2006. Metode Penelitian Survei. LP3ES. Jakarta

Soekartawi, 1995. Analisis Usahatani. Jakarta: Universitas Indonesia.

Soekartawi, 1993. Agribisnis Teori Dan Aplikasinya. Jakarta: PT. Raja Grafindo Persada.

Sukirno, S. 2006. Makroekonomi. Raja Grafindo Persada. Jakarta.

Sugiyono. 2010. Metode Penelitian Kuantitatif Kualitatif dan $R \& D$. Bandung: Alfabeta.

Sugiyono. 2009. Memahami Penelitian Kualitatif. Bandung: Alfabeta 